\title{
The Role of the Principal in Facilitating Professional Development of the Self and Teachers in Primary Schools in South Africa
}

\author{
Vimbi P. Mahlangu \\ Department of Education Management and Policy studies, Faculty of Education, \\ University of Pretoria, South Africa, Corner Leyds and George Storrar Avenue, \\ Groenkloof Campus Pretoria, 0002, South Africa \\ Telephone: +27 12420 5624, Fax: +27 12420 3581, \\ E-mail: vimbi.mahlangu@up.ac.za
}

KEYWORDS Professional Development. Primary School. Principal. Teacher. Rural Area. Urban Area

\begin{abstract}
This study investigates principal-teacher development in four primary schools in the Limpopo Province, South Africa. The rationale is to understand how principals develop themselves and their teachers to bring change in their practice through staff development. This study uses qualitative and quantitative approaches and the qualitative approach is more dominant. Four principals were purposively selected for the purposes of the study. Semi-structured interviews were conducted with the principals of the four schools and a questionnaire was completed by 89 educators in the four selected schools. The methods used in collecting data were through a semistructured interview and a questionnaire. The conceptual framework of this paper was based on who is responsible for the initiation of staff development for both the principal and the teachers in the primary schools. What knowledge and skills do principals and teachers have concerning principal-teacher development in the school. Principals are developed through workshops
\end{abstract}

\section{INTRODUCTION}

In modelling the formation of the staff competitiveness the principle of transparency, implying openness and accessibility of the staff members' achievements must be maintained (Ivanenko et al. 2015: 40). Some problems that need to be dealt with in staff development amongst others are the lack of a shared perception and agreement on the objectives of the school by staff and stakeholders; the lack of commitment to the school by the team, management and stakeholders; and unclear lines of authority and responsibility; and poor or no analysis of major risk factors (Youker 2015: 1).

This paper emanates from a study that was conducted in four primary schools in the Limpopo Province. Limpopo Province is one of the nine provinces of the Republic of South Africa. Limpopo is South Africa's northernmost province, lying within the great curve of the Limpopo River. It is a region of contrasts, from true bushveld country to majestic mountains, primeval indigenous forests, unspoilt wilderness and patchworks of farmland. The province borders the countries of Botswana to the west, Zimbabwe to the north and Mozambique to the east. In the eastern region lies the northern half of the magnificent Kruger National Park, a nature reserve teeming with African wildlife in a total area roughly the size of Israel. Limpopo is the gateway to the rest of Africa, with its shared borders making it favourably situated for economic cooperation with other parts of southern Africa.

This paper investigates the role of the principal in facilitating teacher development as well as principal development in schools in both rural and urban schools. In both rural and urban school settings teachers often enter the teaching profession with insufficient understanding of or experience with the diverse characteristics and needs of children in the geographic regions outside their university location (Hickey and Lanahan 2012). Teachers cannot be trained once and for all. They need constant updating in new technology, pedagogic improvement and personal leadership development (Tomlinson 1997). Professional development in this context refers to the principals when they update individual knowledge, skills, application of new strategies and changes as well as improving their teachers' expertise. It is for individuals or groups with like needs identified by them or the school is career-orientated or personal and is longer term (Tomlinson 1997).

The principal has the following roles to play: in-service training of teachers in terms of new 
curriculum (instructional leadership) and policies, staff development (conditions of service, dispute resolution mechanisms, curriculum innovation, communication, leadership and management skills, capacity building, interpersonal skills, teaching and learning, cultural tolerance), communication (district and school, school and community). As well as developing leadership talent (accountability, relationships, trust, Ubuntu (humanness), democratic leadership styles, and constitutional values).

Most leadership preparation programs have historically focused on management skills (for example, planning, strategic leadership, and financing; which are necessary but insufficient for meeting the adaptive challenges leaders of all kinds face in today's world. Instead, programs need a more holistic focus, one that also includes relational learning that is, a focus on building relationships), collaborative leadership, and reflective practice, and leaders must understand the nature of adult learning, the social-emotional dimension of leadership, adult development, and how to support these among adults in schools (Drago-Severson et al. 2012). Adult developmental theories can be a powerful tool for understanding how to support leadership development and how to assist leaders with supporting adults as they develop greater internal capacities to effectively exercise good leadership in schools (Ibid 2012).

\section{Objectives of the Study}

The objectives of the study were to investigate how school principals developed themselves and their teachers in primary schools. The aim was to explore previously unexplored role of the principal in self and in principal-teacher development of teachers within the contexts of primary schools with the intention of understanding how teachers bring change in their practice through staff development.

\section{METHODOLOGY}

Qualitative and quantitative approaches were used in investigating the role of the principal in the facilitation of teacher and principal development in schools. The qualitative approach was dominant because the researcher relied on the views of participants; asks broad and general questions; collects data consisting largely of words or texts from participants; describes and analyses these words or themes and conducts the inquiry in a subjective, biased manner (Creswell 2008). This approach is the most appropriate for this study because the researcher needed to describe the principals' experiences in a subjective and contextualised situation, Desk top research, observation, interviews, tape-recording and shadowing was done. Interviews were conducted with the principals of the four schools and a questionnaire completed by 89 educators in the four selected schools. In addition, the researcher completed observation forms and requested school documents from the principals. This study was conducted in four primary schools in the Limpopo Province, South Africa. Four principals were purposively selected for the purpose of the study. Semi-structured interviews were conducted with the principals of the four schools and a questionnaire was completed by 89 educators in the four selected schools. 80 percent of the respondents were teachers at Post level 1, 16 percent were Heads of department (HoDs), and 5 percent were deputy principals. The educational level of the respondents were as follows: Matric/Grade 12+1year were 3.4 percent; Matric/Grade 12+2 years were 3.4 percent, Matric/Grade $12+3$ years were 47 percent, Bachelor's Degree were 15 percent, Honours degree or equivalent were 27.3 percent, Masters' Degree were 1.1 percent, and 3.4 percent had other educational levels. The respondents' response rate was 100 percent in terms of questionnaire return.

\section{The Aim of Staff Development}

Staff development must focus on job or program orientation, deficit correction, and inspiration (Bradley et al. 1991). Principals in primary schools must be aware that educators develop through different stages in their careers. Staff development is those processes that improve the job-related knowledge, skills, or attitudes of school employees. There are five models of staff development, namely: individually-guided staff development (educators learn things on their own), observation/assessment; educator involvement in development/improvement pro- 
cess; training; and inquiry (Sparks and LoucksHorsley 1989).

\section{Teachers' Stages of Development}

\section{Self-protective Stage}

Teachers at this stage may use rules to their advantage. Blame is placed on other individuals or the circumstances when satisfaction is not achieved. Principals must be aware that teachers who stay at this stage maintain manipulative and exploitive interpersonal relations and tend to be opportunistic, and preoccupied with control and advantage.

\section{Conformist Stage}

At this stage teachers obey rules simply because they are group-accepted rules. Teachers at this stage are preoccupied with appearance, social acceptance and reputation.

\section{Self-aware Transition}

Teachers at this stage are appreciate understand that there is a multiple of possibilities, alternatives, and options in problem-solving situations. Growing self-confidence and self-evaluated standards replace group standards as guidelines for behaviour.

\section{Conscientious Stage}

At this stage teachers are capable of selfcriticism. They are preoccupied with obligations, privileges, rights, ideals, traits, and achievement, all defined more by inner standards and less by the need for external recognition and acceptance.

\section{Individualistic Transition}

Teachers at this stage tend to have more complex responses than those at earlier stages. A sense of individuality is of utmost importance, especially as it is coupled with heightened awareness of emotional dependence on others.

\section{Autonomous Stage}

Teachers at this stage have the capacity to tolerate and cope with the inner conflict that arises between conflicting perceptions, needs, ideals, and duties (Holly and Mcloughlin 1989).

\section{The Role of the Principal}

The principal can play a role in the in-service training of teachers in terms of new curriculum (instructional leadership), policies; staff development (conditions of service, dispute resolution mechanisms, curriculum innovation, communication, leadership and management skills, capacity building, interpersonal skills, teaching and learning, cultural tolerance), facilitating communication (district and school, school and community). Some of the roles may be the development of leadership talent in accountability, relationships, trust, ubuntu, democratic leadership styles, and constitutional values. School leaders remain of crucial importance for continued improvement of education. Within schools that are learning organisations evolve new types of relationship between students, teachers and leaders based around a reasonably common set of characteristics that include a trusting and collaborative climate, a shared and monitored mission, taking initiatives and risks, and on-going, relevant professional development (Mulford 2003).

In understanding the role of the principal one need to ask "What is the leadership role of the principal?” In this paper leadership is about providing direction, assuring alignment, building a commitment in educators and, facing adaptive challenges. The principal should be able to fulfil the leadership outcomes. The building of talent on the team, the increasing of individual and team energy, and the clarification of individual and team focus should be a priority. Professional teaching is undermined by alternatives that avoid preparation for teachers because the defining features of a profession are that it is knowledge-based and client oriented. The knowledge professionals need in order to make sound decisions is transmitted through professional education and by initiation through supervised practice (Darling-Hammond et al. 1998).

This paper argues in favour of applied transformational leadership. Each of us has our own unique set of skills, abilities and potential. Peak performance comes from matching our unique capabilities with our responsibilities. Great leadership results are produced by maximizing our strengths. Overcoming competency gaps turbo-charges the use of these strengths (Hollweg 2003). Applied transformational leadership encompasses the act of empowering individuals 
to fulfill their contractual obligations, meet the needs of the school, and go beyond the "call of duty" for the betterment of the institution (Santamaria and Santamaria 2012).

These leaders inspire, motivate, and appeal to followers through an array of skills and behaviours, which communicate their value to the institution. They serve as role models to others, modelling the characteristics, behaviours, and actions that they seek from all the members of the organisation. The benefits of this leadership style are that the leaders improve the bottom line, which occurs as employees regularly surpass expectations; morale is increased through leaders' efforts to fully integrate followers into the core functions of the institution. Transformational leadership has a moral imperative wherein leaders aim to destroy old ways of life to make way for new ways of life, while articulating vision and values to keep empowered followers on a unified path (Santamaria and Santamaria 2012). These leaders redistribute power to their followers regardless of culture.

The school leadership should be purposive, inclusive, values driven; embrace the distinctive and inclusive context of the school; and to promote an active view of learning. It should be instructionally focused; it should be a function that is distributed throughout the school community. It needs to build capacity by developing the school as a learning community. For the leadership to be relevant it must be futures oriented and strategically driven. It must be developed through experiential and innovative methodologies. It needs to be served by a support and policy context that is coherent and implementation driven. Lastly, it should be supported by a National College that leads the discourse around leadership for learning (Crow 2004).

\section{The Role of the Principal in Instructional Leadership}

The school principal as instructional leader must first have a clear understanding of what teaching is in order to design a staff development program that will improve teaching (Bradley et al. 1991). Instructional leaders should be able to define the school's mission (framing and communicating goals); to manage the instructional program (supervising instruction, coordinating curriculum, and monitoring student progress), and to promote a positive school learning climate (protecting instructional time, professional development, a visible presence, promoting high expectations, and providing incentives for teachers and students. Principals as instructional leadership should focus on those school-level factors that will "trickle down," altering teaching and learning at the classroom level (Neumerski 2012).

Teacher development should focus on the following knowledge base, namely: knowledge about learners and learning (learners and learning; knowledge of the learner; meeting developmental needs of learners. Knowledge about curriculum and teaching (the need for a curricular vision of teaching; subject-specific pedagogy; conceptions of teaching; knowledge about reading and writing; classroom organisation and management, and effective classroom guidance); Knowledge about social foundations of education (social and political contexts, the dynamics of school district; social organisation of classes and schools; principles of sociology and anthropology, context, code, classroom and culture; professional knowledge; professional collaboration; ethical dimensions of teaching; legal rights and responsibilities); Knowledge about subject matter (subject-matter knowledge for teaching); and Knowledge about liberal arts (knowledge, representation, and quantitative thinking) (Darling-Hammond et al. 1998).

\section{The Role of the Principal in Informational and Transformational Learning}

Informational learning refers to increasing facts, knowledge, and skills, which are very important in our $21^{\text {st }}$ century world. However, there is another kind of learning, one that builds internal capacities. Transformational learning which is also essential. This kind of learning (that is, growth) pertains to increases in our cognitive, emotional, interpersonal, and intrapersonal capacities, which enables us to better manage the complexities of leadership, teaching, leading, and life. Attending to and supporting transformational learning in school leaders can help in building leaders, schools, and school systems so that they can implement leadership practices and enhance professional learning opportunities ((Drago-Severson et al. 2012). The increasing range and complexity of leadership responsibilities in schools means that it is no longer possible for the principal to be the sole leader (Juni- 
nah Junainah Dullah, Ministry Of Education Sabariah Sharif, Universiti Malaysia Sabah Mohamad Nizam Nazarudin, Universiti Malaysia Sabah M.S. Omar-Fauzee.

The development of principals differs from country to country. The examples below illustrate this point.

\section{School Leadership Development Programmes}

School leadership programs take different forms in different countries. For example, qualification for school leaders in Hong Kong China takes place in the form of Induction Course. It is also provided by the Education Department (ED) of Hong Kong. This induction course is for the newly appointed school principals. The methods used in developing the newly appointed principals are in the form of lectures by guest speakers, through discussion, and case studies. In South Africa the qualification for school leaders is the Advanced Certificate in Education (ACE). It is provided by the Department of Education through the University of Pretoria. It is for the permanently employed practicing primary and secondary school principals. The methods used in developing the principals are in the form of lectures by lecturers, portfolios, and through mentoring. In Washington, USA principals are developed through the Danforth Educational Leadership Program of the University of Washington. It is provided by the College of Education of the University of Washington, Seattle. It is for applicants for the position of Principal in the state of Washington. Methods used include simulations, case studies, role-play, interactive discussion, the completion of concrete leadership tasks during work experience, and through personal study. In Singapore the qualification for school leaders include a Diploma in Educational Administration. It is provided by the National Institute of Education of Nanyang Technological University. It targets teachers before application for principalship. Methods used in their training are in the form of: lectures, seminars, workshops, tutorials, and mentoring.

\section{OBSERVATIONS}

Each school's findings will be presented separately. The role of the principal in the development of educators in each school is discussed below. The names of the schools are fictitious to protect the confidentiality of the participants in the study.

\section{Meritorious Primary School}

The principal encourages teachers to enroll with institutions of higher learning to develop them. Teachers are given university brochures and encouraged to further their studies. Teachers are developed only one day by their circuit and by doing so, the circuit is trying to save money.

\section{Nightingale Primary School}

At school B the principal was still working on a SWOT analysis. The completion of the SWOT analysis will assist the principal in developing teachers. In every briefing, every meeting there is always an item on staff development. Educators were presented with all different types of leaves. Teachers at this school are informed about the procedure to be followed in terms of submission of forms. According to the principal at School B that capacity building was really necessary. Teachers at this school they know what is happening in the school. Curriculum management is done by the School Management Team. It was also regarded as the loophole (challenge) by the principal. The school still has a long way to go. It has until May 2015 to improve the management of the curriculum. The School Management Team is still identifying areas where the educators need development. The reason why the principal and the School Management Team don't have a development plan is that they are still busy with completing a SWOT analysis. A cluster coordinator for Integrated Quality Management System (IQMS) is used in developing educators.

\section{Mfanawasemakhaya Primary School}

The principal takes teachers through policies, chapter J in the handbook; leave application - it keeps on changing. Chapter G, leave information; National Education Policy Act (NEPA) of 1996, how teachers should perform their duties; the 7 roles of a teacher; computer literacy the school has internet connections teachers are able to download information; and managing the computer. Teachers know a lot of things. They are exposed to facilities. 


\section{Uyangijwayela Primary School}

The principal is playing a leading role in the school because sometimes teachers do not come forward and say that they really need development. He picks up the areas that he feels educators need development. Like the new curriculum from the $4-6$ grades, the principal would look at the samples of their submissions and pick up the problems, for example, if Maths is not planned in the right way then SMT put up a program so that everyone has a common understanding. In the last two terms the school has been working in blocks and educators meet and discussed and straighten up some things. Policy interpretation can be a challenge to educators as they may interpret it in different ways. So if the principal and the teachers have the same interpretation it makes it easy. The school does team planning where two teachers sit together and plan the subject and uses the same approach and that assists a lot. That is what the school does even when they do development mentoring the principal would not leave it to the Heads of Department (HODs) because they may experience challenges.

\section{The Role of the Principal in the Appraisal of Teachers}

\section{Meritorious Primary School}

The principal visits teachers in their classes for appraisal. He gives recommendations to educators in those areas where they need improvement.

\section{Nightingale Primary School}

The principal has a vision, and for him to achieve that vision, he needs other people. Advocacy is very important to the principal. Integrated Quality Management Systems (IQMS) touches all the dimensions. The school had started with the appraisal. By the end of 2013 the school shall be having the School improvement Plan. Those reports will assist the principal and the SMT to compile the School Improvement Plan (SIP). Teachers evaluate themselves. The principal and the SMT check how teachers rate themselves. First few weeks of October they shall be dealing with the peer evaluation. Peer evaluation allows the principal and the SMT to check what are the educators' strengths and weaknesses, including the principal. The principal also needs to be appraised, for example on the 15th October 2013 the principal was scheduled to be assessed for appraisal. The principal will also be reviewed by his immediate senior. Developing a shared vision and culture in the school it is critical that leaders committed to social justice take an active role in helping to articulate a belief and a vision that emphasises the attributes and potential of all involved (Hasazi and Shepherd 2009)

\section{Mfanawasemakhaya Primary School}

The principal train teachers and is a member of the School Development Team (SDT). Since the school had increased in learner enrolment, the principal now deal with two deputy principals and is directly involved with them. He assists the School Management Team members. He checks the files for performance standards 1 to 3 and also number 7 (Extra-curricular). He checks all post levels from teachers to deputy levels. The 1st four performance standards are for classroom performance, numbers 5 to 10 is for HoDs, and numbers 5 to 12 is for Deputy Principals. These are done throughout the year for cycle 1 and 2. He also sits with the DSG to summarise the teachers' scores of performance. The principal and the SMT do not deviate from what is prescribed in law.

\section{Uyangijwayela Primary School}

The school follows an Integrated Quality Management Systems approach. The principal and the SMT have a plan. They do class visits and check the educators' strengths and weaknesses and put up a plan. For example, the teachers who are not good in record keeping or those who are not good in classroom discipline, the principal and the SMT plan on how they can be helped by their peers and how management can assist them in improving. That is the approach the school uses to develop educators in different skills. Educators are firstly given the opportunity to do self-evaluation on what they do about aspects in the key areas like curriculum and co-curricular activities. The school puts up a plan to assist educators in those areas identified for development. Teachers are assisted in lesson planning, assessment and policy issues. 
The principal and the SMT empower the teachers and share with them the standards they want from them. They should not just quickly mark and finish within a day, they want them to be sensitive to the work of the learners. The school had specific standards, for example, a test must be marked in a certain way. The principal and the SMT do quality assurance on the marked scripts. In lesson planning they ask educators to bring their lesson plans and they give suggestions on how to improve them. The school relies on team work. The principal and the SMT also observe educators in their classes. Again, they check the educators' work through the books of the learners. They are able to identify the careless of those educators who do not mark the learners' books. They are also able to see coffee stains which tell them a lot about their teachers' professionalism. The principal visits educators in their classes for appraisal purposes. The principal also gives recommendations where teachers needed improvement.

\section{The Role of the Principals in the Development of the Self}

\section{Meritorious Primary School}

The principal at this did not participate in any workshops, courses or programmes before he became a principal. There was no support provided. The principal had to find his own way of getting information pertaining to principalship. He only attended meetings on how to fill surveys. No Leadership workshops were attended and the principal read on his own some of the Departmental of Education policies.

\section{Nightingale Primary School}

At this school the principal participated in a number of workshops before he became a principal. All along he was working as a teacher who was in possession of a diploma. He obtained a certificate as a qualified assessor. He also obtained a certificate in computers. He has a number of Information Technology Certificates that s/he had obtained. One of them is about a Spread sheet. The principal is a qualified website designer. He has an Advanced Certificate in Education, Leadership and Management. He attended a number of workshops such as the SASAMS (South African School Administration System).
The purpose of SASAMS (South African School Administration System) is to minimize the paperwork. The challenge here was that the school got a problem of pleading with people for compliance. All school are expected to use the SASAMS and they are complying. The circuit manager has emphasized that submission to the circuit must be done electronically.

\section{Mfanawasemakhaya Primary School}

At this school the principal attended programs which were not management programs per se. They were general educational programs in nature. For example, curriculum courses, Revised National Curriculum Statement, introduction of new subjects and all new policies and resolutions. The principal remembers one of the workshops organised by the district, in 1996, in Settlers High by the former Circuit Manager of Modimolle. The other workshops were on Management and Governance. The management workshops were organised by principals and the Governance Workshops were organised by the District officials, on admissions, handling of finances, the same workshops every year. These workshops were also for School Governing Bodies (SGBs). These workshops are used as telling-workshops as to how to handle finances. It is like parrot talk. To this principal these workshops become so obvious because he knows how to deal with the "to do list" (Researcher's comment). The principal also attended courses on new policies, for example, about the Norms and Standards, the South African Schools Act, No.84 of 1996, Section 28b which grants permission to pay School Governing Bodies' (SGBs) appointees.

\section{Uyangijwayela Primary School}

Before becoming a principal, this principal attended quite a number of workshops, courses or programs. From now and then he would be called for meetings and conferences now and then. He benefited from these workshops even though he was not directly involved. There is not such of training apart from information from the universities for his personal growth which they drop in the mail. There were some programs like a year's programs which would assist in curriculum issues but it's very scarce. There are some conferences and symposiums but they are 
very rare. While being a principal, he attended few workshops. The Provincial Department of Education just call principals to give them directives in terms of the Annual National Assessment (ANA) on how to run it or they call them for results. In these workshops there is nothing new. They are used as accountability sessions. Principals are work shopped and told what they already knew. Principals are not motivated to attend these workshops. Some of these workshop initiatives come from private organisations. There was one teacher conference organised by the Department of Education a while ago.

The challenge facing primary schools is the people on the senior posts. Some of them are there not because they qualify to be there but for political reasons. The principal is of the view that people in management positions should be academics and visionary. But it does not happen that way in terms of senior management up there. In schools they are selected but above that it is more of politics. It does not go with suitability and delivery. It is about who is doing what and who can be given the post. The principal would not say with certainty that this is across the board but it is a tendency of appointing political figures. For example, a district where this school is situated is very diverse and if the senior management does not even have a Degree in Management; it will be very difficult to manage it. The person would issue sanctions and avoid academic podiums where people question things. If the leadership or management role above the school level would be filled in a way that is really relevant to the post and what needs to be done it would make a difference in our education.

\section{DISCUSSION}

Pseudonyms were used for each school to maintain confidentiality and anonymity (Long et al. 2015: 8). Globally the significant change in the accountability systems is the consequences faced by principals of schools who fail to meet the accountability system's targets. While school reconstitution was a part of the old accountability system, school principals had a longer period of time to turn their schools around when their schools failed to meet the state's accountability standards (Vaughn and OliverasOrtiz 2015: 10). No single leadership style can suffice thoroughly for the school operation. Integrated leaderships should therefore be represented given the complexity of their multiple utilities (Yeung 2015: 50). Principal-teacher development requires an understanding of the interdependence and interconnectedness of human beings and their environment to teach content related to knowledge of global socio-geopolitical disciplines, and human socio-economic systems (Joshi 2009).

At Meritorious Primary School the principal encourages teachers to enrol with institutions of higher learning to develop them. Teachers are developed only one day by their circuit and by doing so, the circuit is trying to save money. At Nightingale Primary School the School Management Team is still identifying areas where the educators need development. The reason why the principal and the School Management Team don't have a development plan is that they are still busy with completing a SWOT analysis. A cluster coordinator for Integrated Quality Management System (IQMS) is used in developing teachers. At Mfanawasemakhaya Primary School the principal takes teachers through policies, and help them how to perform their duties, especially the 7 roles of a teacher. And at Uyangijwayela Primary School the Provincial Department of Education just call principals to give them directives in terms of the Annual National Assessment (ANA) on how to run it or they call them for results. In these workshops there is nothing new. Principals are work-shopped and told what they already know. Principals are not motivated to attend these workshops. Some of these workshop initiatives come from private organisations.

\section{CONCLUSION}

According to some principals, teachers are developed in only one day by their circuit instead of by them as principals and by so doing, the circuit is trying to save money. Integrated Quality Management System (IQMS) is used in developing teachers in some primary schools in the Limpopo Province of South Africa. Teachers in some of the schools are exposed to facilities. Pertaining to principal development, in the researched schools one principal had to find his own way of getting information pertaining to principalship. Principals are work shopped and told what they already knew. 


\section{RECOMMENDATIONS}

It is recommended that principal-teacher development strategies should consider a holistic approach. Principals and teachers should be developed in aspects such as attitudes, values, management skills, law, human relations, technology and communication skills. Team planning where two teachers sit together and plan can assist in teacher development in primary schools.

\section{REFERENCES}

Bradley MK, Kallick BO, Reagan HB 1991. The Staff Development Manager: A Guide to Professional Growth. U.S.A: Allyn and Bacon.

Creswell JW 2008. Educational Research: Planning, Conducting, and Evaluating Quantitative and Qualitative Research. $3^{\text {rd }}$ Edition. New Jersey: Pearson, Merrill Prentice Hall.

Crow GM 2004. The National College for school leadership: A North American perspective on opportunities and challenges. Educational Management Administration and Leadership, 32: 289.

Drago-Severson E, Maslin-Ostrowski P, Hoffman AM 2012. Resisting fragmentation: Calling for a holistic approach to professional practice and preparation for educational leaders. Journal of Research on Leadership Education, 7(1): 44-77.

Dullah JJ, Sharif S, Nazarudin SMN, Omar-Fauzee SMS (n.d.). Headmaster's Transformational Leadership and Teacher's Organisational Commitment in Primary School. (Retrieved on 3 June 2013).

Darling-Hammond L, Wise AE, Klein SP 1999. A License to Teach: Raising Standards for Teaching. San Francisco: Jossey-Bass Publishers.

Hasazi S, Shepherd K 2009. Leading beyond labels: The role of the principal in leading through a social justice framework for students with disabilities. A twenty-first century approach to teaching social justice: Educating for both advocacy and action. Counterpoints, 358: 91-106

Hickey MG, Lanahan BK 2012. Even the Janitor is White: Educating for Cultural Diversity in Small Colleges and Universities. New York: Peter Lang.
Hollweg L 2003. Strength-focused Transformational Leadership. Insight Papers. Texas: Batrushollweg International.

Holly ML, Mcloughlin CS 1989. Perspectives on Teacher Professional Development: Issues in Education and Training Series 11. London: The Falmer Press.

Ivanenko NA, Akhmetov LG, Lavrentiev SY, Kartashova EP, Lezhnina LV, Tzaregorodtzeva KA, Khairullina ER 2015. Features of modeling the formation of teaching staff competitiveness. Review of European Studies, 7(3): 37-42.

Joshi U 2009. Education for sustainable development: The role of universities. International Forum of Teaching and Studies, 5(1): 62-67.

Long LC, Barnett K, Rogers B 2015. Exploring the relationship between principal, policy, and gifted program scope and quality. Journal for the Education of the Gifted, 2015: 1-23.

Mulford B 2003. School Leaders: Changing Roles and Impact on Teachers and School Effectiveness. A Paper Commissioned by the Education and Training Policy Division, OECD, for the Activity Attracting, Developing and Retaining Effective Teachers, Tasmania, April 2003.

Neumerski CM 2012. Rethinking instructional leadership, a review: What do we know about principal, teacher, and coach instructional leadership, and where should we go from here? Educational Administration Quarterly, 49: 310.

Santamaria LJ, Santamaria AP 2012. Applied Critical Leadership in Education: Choosing Change. New York: Routledge.

Sparks D, Loucks-Horsley S 1989. Five models of staff development for teachers. Journal of Staff Development, 10(4): 40-57.

Tomlinson H 1997. Managing Continuing Professional Development in Schools. London: Paul Chapman Publishing.

Vaughn V, Oliveras-Ortiz Y 2015. Considering an overhaul to the new principal preparation program. School Leadership Review, 10(1): 1-62.

Yeung HCO 2015. Case study on the principal leaderships utilised in a Hong Kong special secondary school setting in the NSS educational reform. International Journal of Education, 7(1): 44-56.

Youker R 2015. Managing international development projects: Lessons learned. Project Manage J, 30(2): $6-7$. 